\title{
Advertisements: Hi-language for Hi-tech?
}

\author{
Tran Thi Thu Hien ${ }^{1}$ \\ ${ }^{1}$ University of Languages and International Studies, Vietnam National University, Hanoi, Vietnam \\ Correspondence: Tran Thi Thu Hien, University of Languages and International Studies, Vietnam National \\ University, Hanoi, Vietnam. Tel: 84-98-335-2963. E-mail: hienesp@gmail.com
}

Received: December 15, $2011 \quad$ Accepted: January 18, $2012 \quad$ Published: May 1, 2012

doi:10.5539/ass.v8n6p86

URL: http://dx.doi.org/10.5539/ass.v8n6p86

\begin{abstract}
Language of advertising is considered special and very much different from normal language. It is the linguistic power created in advertisements makes them an important part in our social life. This article looks at particular group of product advertised, that is hi-tech product. Through the selected advertisements, it aims at whether or not the advertisers of these ads use high language to promote their hi-end merchandises. Also, from the perspective of contrastive analysis, the paper compares these English and Vietnamese advertisements to find out if there are any similarities and differences in the language used in terms of phonological, lexical and grammatical level.
\end{abstract}

Keywords: advertising, hi-tech, language, English advertisements, Vietnamese advertisements

\section{Introduction}

It cannot be denied that advertising has a powerful and widespread influence on every member and corner of the society. With the irresistible expansion of advertisements, advertising is now not only a closely related but an unseparatable part in our life. By means of its linguistic power, advertising has placed a strong effect on social life and language style. The language used in advertisements has evolved from common language into a professional style. It is because languages used in advertising has no longer acted as common ones in daily life but set their own and unique styles. Surely, together with huge advancement in science and technology, advertising and its languages have changed rapidly. This paper looks at the languages used in hi-tech advertisements in Vietnamese and English from contrastive analysis perspective. It aims at answering the question: whether or not the language used in the field advertisements is affected by the products addressed.

\section{Advertising}

In general, advertising is a means of communication between the sponsor and the advertisement recipients. Besides, advertisements can be either commercial or non-commercial ones. The former focuses on bringing as much as profit for the producer while the later is not for profit but aims at fostering the community benefit. As a matter of fact, commercial advertisements can be found with much higher proportion in mass media (Nguyen \& Tran: 1993). Therefore, most of the efforts in defining advertising have been placed on commercial advertisements.

Broadly, advertising is a device to arrest attention. This reflects Leonard's thought:

"Advertising is as old as Humanity: indeed, much older; for what are the flaunting colors of the flowers but so many invitations to the bees to come and "buy our product". Everything is already there: the striking forms, the brilliant hues, even the "conditioning of the customer".... Advertising might be defined as any device which first arrests the attention of the passer-by and then induces him to accept a mutually advantageous exchange"

(Leonard: 1968)

Obviously, in our life there are many ways to arrest human attention and only some are advertisements. Although, the above definition does not manage to distinguish advertising from other attention grabbers, it does 
emphasize important features of advertisements: exchange, attention and mutuality. In combining all these things together - over time, place, and cultural boundaries, the above definition highlight the antiquity of advertising that is, rather than being something created yesterday, it is as old as humanity and as universal as culture. Advertising, seen in this light, is therefore, a part of our social life.

It is certain that advertising is more prominent in the hi-tech (capitalist) society of the western world than it is in other countries. It is a discourse type that is quick obtaining so much importance and is helping to create a new global culture that cut across national boundaries. (Guy Cook, 1992). Cook's idea of advertising is similar to his British pioneer, Raymond Williams who simply calls advertising "The official art of the capitalist society" which emphasizes sponsorship of art in modern times. In exploring this catching phrase, the first thing to note down is that advertising is located in social context. It is viewed as a part of modern capitalist society, and this differentiates it from attention-grabbing devices in non-capitalist societies in other times and places and that is to say, advertising cannot be separated from the way it comes into being and the work it does in society.

If Leonard's definition of advertising as an attention-grabbing tool centers around the antiquity of advertising, Williams' definition of advertising as sponsored art seeks attention to its modernity. A question arisen is: Which is true? The answer is: Both, as each definition brings out a radically different aspect of advertising.

In other ways and from other perspectives, advertising is viewed as "mediated communication", "commercial speech", "ways of selling cornflakes to other people who are eating cheerios" or "a form of mythmaking" or "a speed act”, etc. (Lasker: 1963, Marchand: 1985, Randazzo: 1993, Deresiewicz: 1998, Mai Xuan Huy, 2005). So what is advertising? Surely, it is a multifaceted phenomenon - closely tied to society, culture, history, and the economy with some universal aspects as well as culturally specific ones.

In this paper, advertising is viewed as an impersonal way communication broadcasted by the mass media. It is paid, indirect and one-way communication from the seller (the producer/ the advertisement sponsor) to the potential customers (the readers/ the audience). In terms of content, the advertising provides the information about the products to be sold. In terms of characteristics, the advertising is the sell-applause of the producer. In terms of objective, the advertising aims at completely influencing the advertisement receivers to persuade them to buy the advertised products. Above all, from the communicative perspective, advertising is the art of using language.

\section{Advertising Language}

Interestingly, the language of advertising is very special and is very much different from the so-called "normal language" and unusual aspects of language found in advertisements is considered examples of "artful deviations" (Sells \& Gonzales)

In his early and detailed research on the language of advertising, Leech (1996) points out that most of the advertising language is hidden under a potential power aiming at changing the need, opinion and behaviors of the advertising recipients. He also states that advertising language is of common and colloquial style because it is very difficult to use formal language in advertisements since the formal language requires both the user and the recipients must be in a certain education background. Common and colloquial style, therefore, is in favor of the advertisers as they want their advertisements to be taken and accepted by a large numbers of customers of any education background.

Dyer, G. (1982) holds that, language is used in advertisements to embed ideas of the product's image into the audience so the language used in advertisements must be highly impressive and persuasive.

From another perspective, Vestergaard \& Schrodder (1985) consider advertising language a means of brand promotion and they state that the main reason after the languages used in advertisements is the purpose of increasing the familiarity and the liking towards the image of the producer rather than the product being advertised.

In their research, Scholes \& Comely (1989) believes that advertising "seeks to direct our attention and our emotions towards some product" namely, our senses and emotions are all involved in the process of receiving and understanding a successful advertisement.

According to Andrew Hart (1991), advertisements have "very basic messages to offer and they are expressed in very memorable, often humorous ways" It is the "very memorable, often humorous ways" advertisements express their message that makes the language of advertising very interesting as a field of study. 
Meanwhile, Guy Cook (1992) studies advertisement from the view of discourse analysis, that is the study on the analysis of the language, content, the interaction and the persuasive feature of the language - considered the functions of advertising. This view is shared by Leech (1966) when he asserts that any aspect of using language is also an aspect of discourse. He describes the discourse style in advertising language is either formal or informal, with personal pronouns or impersonal, is either simple or complex, ... depends on the subjects the advertisements aim at.

Later, Angela Goddart (1998) finds out that there exists a relationship between language and images used in advertisements, between advertisements and culture, between the advertisements and the audience. She states that advertising is an indispensable bridge between the sellers and the buyers in every economy.

In brief, linguists all over the world have researched on advertising language in its different aspects and whether the concept expressed in different ways with different languages, it comes to the conclusion that:

(i) Advertising language is diverse and whether it is informal or not much depends on the subjects addressed in the advertisements

(ii) Advertising language is highly impressive or persuasive to obtain the main purpose of advertising that is to seek the potential customers' attention.

(iii) Advertising language exists in a close relationship with other elements of the advertisements to make it successful.

(iv) Advertising language reflects and implies culture. It is creating a global culture which is actively operating between the sellers and the buyers.

\section{Advertising Language for Hi-tech Products}

In order to study the use of language in advertisements for hi-tech products, a sample of approximately 400 newspaper and magazine advertisements in English and Vietnamese was composed. All newspaper and magazine issues were from the last four years (2008-2011). After duplicate advertisements were identified, the second advertisement was not considered. A total of 222 advertisements were sampled in the corpus, 127 English advertisements and 95 Vietnamese ones. The selected advertisements can be categorized in different groups as seen in Table 1.

Table 1. Advertisements of hi-tech products

\begin{tabular}{cccccccccccc}
\hline & $\begin{array}{c}\text { Web } \\
\text { service }\end{array}$ & Server Tablet & PC & $\begin{array}{c}\text { Portable } \\
\text { computer }\end{array}$ & Application & $\begin{array}{c}\text { Storage } \\
\text { device }\end{array}$ & $\begin{array}{c}\text { Net } \\
\text { supporting } \\
\text { unit }\end{array}$ & Peripheral Hardware E-reader Total \\
\hline English & 105 & 0 & 0 & 0 & 4 & 4 & 1 & 0 & 5 & 0 & 5 \\
\hline Vietnamese & 0 & 5 & 1 & 4 & 31 & 12 & 10 & 4 & 16 & 12 & 0 \\
\hline Total & 105 & 5 & 1 & 4 & 35 & 16 & 11 & 4 & 21 & 12 & 5 \\
\hline
\end{tabular}

The first impression brought by these advertisements is that they aim at intellectuals, relatively high income and hi-tech knowledgeable people.

The second thing to consider is the significant differences in the total numbers of Vietnamese and English advertisements as well as sub-types of the hi-tech products advertised. In particular, the number of English advertisements is higher than that of the Vietnamese ones (57\% and $43 \%$ relatively). Laptops are the products advertised most in Vietnamese (31 ads, account for $32.5 \%$ of Vietnamese advertisements) while web services are in this position in English ads (105 ads, make up 47\% of English advertisements). Some products such as tablets, hardware, personal computers, etc. are marketed much in Vietnamese but not in English. On the contrary, advertisements promoting such hi-tech products as Kindle and web services can only be found in English.

Reasonably, differences in terms of total numbers and sub-type products can be explained by technology background in Vietnam. Vietnam is still in the first phase of applying hi-tech products so to win the market, Vietnamese advertisers set their priority on selling products used for equipping and building infrastructures and 
setting the foundation for the hi-tech application in the next phases of development in the future. Meanwhile, countries such as Britain, American, etc. are leading countries in technology and they are surely no longer in the starting phases but hi-tech advancement. Advertisements in these countries, therefore, are for developed economies with e-commerce and technology for life. Let's take Kindle as an example, this product is popular in stores and online shops in America but an advertisement of this is not found in Vietnam.

Besides, there is a repetition in Vietnamese advertisements. The same advertisements of one product can found in a series of a newspaper or many magazines. In the meantime, many English ad versions of the same product can be found in the same newspaper and magazine, usually 5-7 versions in average. Thus, advertisements in IBM's Smarter Planet project is considered exceptional with 7 versions in Vietnam seem to be nothing in comparison to its 19 creative and diverse English ones.

This situation of Vietnamese advertisements can be contributed by financial competence of Vietnamese companies but it may also because of their advertising strategies and their opinions towards advertising. Many Vietnamese companies misestimate the role of advertising to the growth of their companies so they have not put enough money and attention on advertising yet. As a result, through the study on 95 Vietnamese advertisements and 127 English ads on hi-tech products, we have to admit that Vietnamese advertisements just introduce, not advertise as the word really means, the products to the market and have not tried to persuade the customers while the English ads are successful in creating impression and arousing the need of buying products in their clients.

\subsection{Phonological Features}

\subsubsection{Rhymes}

In both English and Vietnamese advertisements studied, we note that rhymes are used in many headlines to attract the readers' attention. By this kind of rhyming, the headlines are broken into even rhythms. The advertising headlines are hence highly purposeful. It makes the headlines easier to memorize, easier to absorb and live longer in the readers' minds. For example, in one of its software advertisements for gathering family's information and creating family's history, the Palladium web site says:

[1] She has her mother's eyes,

Her father's smiles, and

Her uncle's web site. (Family Gathering CD-ROM)

Here, the rhymes created by "eyes - smiles - site" surely make the headlines catchier.

In other case, in order to attract iPad users to use their applications, Zinio presents a long bench and writes below:

\section{[2] You see a bench. We see a newsstand.}

Find thousands of magazines available instantly on your iPad, where you are." (iPad newsreader)

In this ad, the advertiser does not use many words. However, by combining the visual rhetoric of a bench with the word of "newsstand" (which goes well with "bench") and the repetition of the simple structure "You see a..." - "We see a..." the advertisement has successfully conveyed its objectives and won the readers' hearts.

This can also be found in Vietnamese ads. In Acer e-machines laptops, the advertiser puts the headline like that:
[3] Cấu hình thật đã ,
Good configuration,

Giá cả cực sốc.” (Acer e-machines)

Contented price"

Or one of the Dell's advertisements for its laptops and personal computers at Christmas season in 2009 says:

[4] Đón Giáng sinh tưng bùng,

Mùng năm mới rộn rã. (Dell)

\section{Enjoy Christmas,}

Rejoice New Year.

In these two above Vietnamese advertisements, each headline is broken into 2 lines of four or five words with the last word of the first line goes in harmony with the first or the second word of the second line. Moreover, the advertisements are more successful with the additional style of the words used. Acer laptops aim at the youth, so the advertiser applies colloquial style with words like "đã " and "cưc sốc" used much by young people while the Dell's advertisement focus much on the season of Christmas and New Year when the shops in Vietnam start selling off. 


\subsubsection{Repetition}

Repetition of words or part of words can be used to help advertising phases especially, headlines build strong beating rhythms to make them even and unforgettable. The following types of repetition are popular in the studied advertisements in both English and Vietnamese:

a. Anaphora: The first word of a phrase is repeated in the next one. For examples,

[5] Get connected. Get Teamcenter for smarter PLM" (Siemens)

\section{- Building cities worth}

Building a future in." (Siemens)

Or: [6] Siêu mỏng - Siêu mạnh - Siêu thời gian.” (Acer Timeline X)

(Super thin - Super powerful - Super timeline)

b. Epistrope: The last word of a phrase is repeated in the next one. For examples,

[7] Mạnh mẽ hơn.

Tiết kiệm hon." (Dell Inspiron 1464 \& 1564)

(More powerful.

More saving."

c. Assonance: A syllable of a word is repeated in the next part of the phrase. For example,

[8] Dual-core.

Do more. (FPT Elead SP540)

d. Parison: Structure of a phrase or a sentence is repeated in the same length, same rhythm, same tone or in all the three features. For examples,

[9] Simplicity is power. ...

Simplicity is essential....

Simplicity is flexibility....

Simplicity is savings..." (Citrix)

Or: [10] Tận hưởng âm thanh. Cảm nhận sức mạnh.” (Asus N Series)

(Enjoy the sound. Experience the power.)

\subsection{Lexical Features}

The most distinctive lexical feature of the studied advertisements is the high density of technology terms used in Vietnamese advertisements. All of the 95 Vietnamese advertisements use technology terminology with an unusual frequency. In average, a Vietnamese advertisement has 14 terms with the highest number of terms in an advertisement is 50 and the lowest numbers of term employed is 4 terms in one ad. In contrast, 96 English advertisements (account for 43\%) have no terminology in the content. In average, there are 3 terms in one English advertisement. Rarely, the highest numbers of terms is 14 in an ad made by Google.

Additionally, advertisements for hi-tech products in Vietnam also use many loan words, mostly borrowed from English meanwhile no foreign-original words are found in English ads. It is because technology in Vietnam is inherited from hi-tech advancement from the world-wide developed countries especially, English speaking countries. Naturally, English advertisers do not have to borrow terms from other languages because most of the terms are already in English. Meanwhile, many English terms do not have Vietnamese equivalents and in most of the cases, they are brought to Vietnamese by lending the whole term or part of the term, translating, explaining or transcribing, etc... in which borrowing the whole term is most popular in advertisements of hi-tech products in Vietnam. For example, 


\section{[11] ACER ASPIRE 4745(G) \& ASPIRE 4741(G)}

\section{BỘ ĐÔI HOÀN HẢO}

Cùng chiêm ngưỡng bộ đôi laptop "trai tài gái sắc" của làng công nghệ Việt Nam năm 2010. Với thiết kế hiện đại, thời trang và cấu hình vượt trội, Acer Aspire $4741(\mathrm{G})$ và Aspire $4745(\mathrm{G})$ hứa hẹn mang lại cho bạn những trải nghiệm đầy thú vị.

\section{ACER ASPIRE 4745(G) DUYÊN DÁNG DÀNH CHO NÀNG}

Lấy cảm hứng từ những đường kẻ sọc thanh mảnh của thòi trang Burberry kết hợp với các xu hướng trở lại của các chất liệu thiên nhiên, Acer 4745 phiên bản năm 2010 với vân gỗ chìm trên nền máy đen bóng mang lại một vẻ ngoài hoàn toàn mới, sang trọng và tinh tế hơn, trở thành một món quà công nghệ quyến rũ và khó lòng cưỡng lại.

Điểm nổi bật của chiếc máy này là khả năng giải trí tuyệt vời. Với âm thanh vòm Dolby Home Theatre thế hệ thứ 3 và màn hình Led Backlit 16:9, các buổi ci-nê tại nhà của bạn sống động hơn bao giờ hết. Bạn cũng có thể tự tạo cho mình các thu muc quản lí âm nhạc, hình ảnh và các chia sẻ các nhân một cách khoa học và dễ dàng nhất. Đặc biệt, máy được trang bị angten PIFA mở rộng vùng quét sóng và Webcam Acer Crystal Eye với độ phân giải 1.3MP, giờ đây cả thế giới nằm trong tay bạn.

\section{ACER ASPIRE $474(G)$ \\ LICH LÃM DÀNH CHO CHÀNG}

Vẻ ngoài mạnh mẽ, thiết kế thông minh, Acer Aspire 4741(G) là sự lựa chọn tuyệt vời cho những ai đam mê công việc những vẫn muốn cân bằng và tận hưởng cuộc sống. Hai màu xám bạc, đen và $x u$ huoóng metallic trong các thiết kế Prada, Missoni và Alexander McQueen được ứng dụng sáng tạo trong cá thiết kế mới nhất của Aspire 4741(G). Nền máy giả kim loại với các ô lưới nhỏ đan xen nhau mang lại cho Aspire 4741(G) vẻ mạnh mẽ và đầy sức hút.

Ngoài ra, Acer Aspire 4741(G) có thể tăng tốc xủ lí hơn 20\% đa nhiệm so với dòng chip Core 2 Duo trước đây. Với bộ vi xử lí Intel Core i5-430 (2.26 GHz ép xung lên 2.53GHz) hỗ trọ Turbo Boost, RAM 2GB - DDR3, ổ cúng 320GB, Card màn hình ATI Mobility Radeon HD 5650/ 5470, Acer Aspire 4741(G) thực thi một cách nhẹ nhàng các ứng dụng cơ bản cho đến các ứng dụng đòi hỏi cấu hình mạnh.

Cùng sánh đôi với laptop Acer Aspire 4741(G) và Aspire 4745(G) để thấy cuộc sống trở nên thú vị và tuyệt vời. Hãy sẵn sàng cho mọi ánh nhìn! (CN21v)

[11] ACER ASPIRE 4745(G) \& ASPIRE 4741(G)

\section{PERFECT COUPLE}

Contemplating the perfect couple of laptop introduced to Vietnam technology in 2010. With their modern, fashionable design and extraordinary configuration, Acer Aspire 4741(G) and Aspire 4745(G) promise to bring you pleasant experiences.

\section{ACER ASPIRE 4745(G) \\ GRACEFUL FOR HER}

Inspired from Burberry slim strips in combination with the recent trend of being close to the nature, Acer 4745 version 2010 with carved veins on polish black background appears with a completely new appearance; more exquisite and more luxurious. It is surely a charming and irresistible hi-tech gift.

The most distinctive feature of this laptop is its capacity for entertainment. With Dolby Home Theatre generation 3 and Led Backlit 16:9, your home cinema will become lively than ever. You can also create folders to manage your music, images and other things to share in the most scientific and easiest way. Especially, the laptop is equipped PIFA antenna with wave scan expandability and Webcam Acer Crystal Eye 1.3MP resolution. For now, the whole world is in your hand.

\section{ACER ASPIRE $474(\mathrm{G})$ \\ ELEGANT FOR HIM}

With its strong appearance and smart design, Acer Aspire 4741(G) is ideal for those who love their work and want to balance their life. Grey and back metallic trend inspired from designs of Prada, Missoni and Alexander McQueen are creatively applied to the newest version of Aspire 4741(G). Pseudo-metallic background with small grids has definitely brought Aspire 4741(G) an attractive and strong appearance.

Additionally, Acer Aspire 4741(G) can do multi-tasking, over clock $20 \%$ compared to the previous chip Core 2 Duo. With its Intel Core i5-430 processor $(2.26 \mathrm{GHz}$ to $2.53 \mathrm{GHz})$ supporting Turbo Boost, RAM 2GB - DDR3, 320GB Hard drive, ATI Mobility Radeon HD 5650/ 5470 VGA card, Acer Aspire 4741(G) can execute all applications from the most basic to the most complicated ones with ease.

Go with laptop Acer Aspire 4741(G) and Aspire 4745(G) to enjoy your wonderful life. Be ready for admired eyes! (CN21v)

And 


\section{[12] IN MY WORLD, THE ROAD IS MY OFFICE.}

PANASONIC TOUGHBOOK COMPUTERS TAKE WHAT THE DAY THROWS AT THEM. My management team and I are always travelling and our Panasonic Toughbook laptops always stand up to bumps, drops and spills. And they are fast enough to run multiple applications. In the three years we have has them, we haven't had a single hardware failure, so the $\boldsymbol{R O I}$ has been significant. We've also save thousands in Wi-fi fees with the embedded mobile broadband. Today's Toughbook computers are even faster with the fastest Intel Processor including the Intel Core i5 vPro processor. (CN4a)

As can be seen from the two advertisements, both of them are about laptops. However, the Vietnamese ad overuses terminology with many terms and borrowed words while the English one just use popular terms which are not very specialized.

It comes to the thought that, advertisers of hi-tech products in Vietnam are still going in their own ways and have not put themselves in the customers' shoes. They tend to show off in technology field with a lot of IT terms and specialized information as if the "hi-language" could guarantee a high rank for the "hi-tech" products they promote. Common Vietnamese people who do not know much about IT will without doubt find it difficult to understand this ad not to mention remembering it. What is more, not many customers know about famous bands in fashion which are usually regarded exclusively for rich people in Vietnam like Burberry, Prada, Missoni và Alexander McQueen. Likewise, people who are acquainted with these luxurious brands may be confused with such IT parameters as Dolby Home Theatre generation 3, Led Backlit 16:9, PIFA antenna, Webcam Acer Crystal Eye 1.3MP resolution, multi-tasking over clock 20\%, chip Core 2 Duo, Intel Core i5-430 microprocessor, Turbo Boost, RAM 2GB - DDR3, 320GB Hard drive, ATI Mobility Radeon HD 5650/ 5470 VGA card, ... All in all, there are many laptop users in Vietnam but not many of them can claim that they fully understand this ad.

In other words, advertisements of hi-tech products in Vietnam tend to use "hi-language" to make customers believe that they are reading about a very high level products. Quite the opposite, English ads of hi-tech products go strait to the practical use of the products to answer the customers' question that how far the products can meet their demand. Because, as a mater of fact, the most important thing to consider in the advertisement about Acer Aspire 4741(G) and Aspire 4745(G) is the Intel Core i5-430 processor and in the advertisement about Panasonic Toughbook laptops is the Intel Core i5 vPro processor.

\subsection{Grammatical Features}

Both English and Vietnamese advertisements sampled in this research mostly use imperative sentences and present simple tense and in resonance with the use of illustrating images. This is sensible as short, simple and clear are common characteristics of the IT field.

\subsubsection{Imperative Sentences}

Short sentences and phrases particularly, special sentences with no subjects are employed much in IT advertisements. For example,

[13] Hãy để màu sắc ấn tượng của chiếc máy tính xách tay thể hiện phong cách của riêng bạn. (Toshiba ecostyle) (Let the impressive colors of the laptop express your style.)

[14] Khám phá thiết kế mới đầy lôi cuốn của dòng laptop Portégé T110/T130. (Toshiba Portégé T110/T130 series) (Explore the new, attractive design of the laptop Portégé T110/T130 series.)

[15] Perfectly performed. (Toshiba r-series)

[16] Come play. (Google TV)

\subsubsection{Present Simple Tense}

All of the ads selected in English and Vietnamese make use of present simple tense to please the customers' desire to know about the present state of the products they intend to buy. Besides, the use of present simple tense also reveals the implication of universality and timelessness.

[17] Stay connected at all times. (Modem Asus ADSL 2+)

\subsubsection{Simple Sentences vs. Complex Sentences}

While English advertisements make use of simple sentences such as:

[18] It is not just business.

It's business, innovated. (Samsung LED Backlit monitor) 
Vietnamese advertisements use a relatively high number of complex sentences with subject - compliment reverse. For example,

[19] Với $\boldsymbol{E R P}$, doanh nghiệp của bạn sẽ được tiếp thêm sức mạnh để thành công hơn. (FPT)

(With ERP, your company will be energized with more power to be more successful.)

[20] Với những cải tiến về thiết kế và được tích hợp các thiết bị tiên tiến, Acer Aspire AS4736 có thể được xem là một rạp hát tại gia dùng để giải trí đa dụng hàng ngày, còn là người bạn đồng hành hỗ trợ tích cực cho bạn trong công việc và học tập. (Acer Aspire AS4736)

(With its innovative design and integrated advanced devices, Acer Aspire AS4736 is considered a home theatre for daily entertainment purposes as well as a helpful supporter in your study and work.)

\section{Conclusion}

After studying advertisements for hi-tech products in both English and Vietnamese in terms of phonological, lexical and grammatical levels, it can be draw that:

(i) Both English and Vietnamese advertisements apply rhymes in headlines to break the headlines into even and rhythming parts, thus, make it catchier and easier to remember.

(ii) Repetition rhetorical devices such as anaphora, epistrope, assonance, parison are employed much in both English and Vietnamese advertisements.

(iii) Vietnamese advertisements use more terminologies than English ads while English ads use more terms of common sense than Vietnamese ones.

(iv) Both advertisements in English and Vietnamese make use of imperative sentences and short phrases. However, Vietnamese advertisements uses more complex sentences than English ads while English ads use more simple sentences in present simple tense.

(v) Above all, advertisers in Vietnam tend to use more complicated language in their advertisements for hi-tech products than their English fellow workers.

\section{References}

Cook, Guy. (1992). The Discourse of Advertising. London: Routledge.

Deresiewicz, William. (1998). Studies in English Literature, 1500-1900, 38(4), 723-740. 740.

Dyer, G. (1982). Advertising as Communication. London: Routledge. http://dx.doi.org/10.4324/9780203328132

Goddard, Angela. (1998). The Language of Advertising. Routledge: London.

Hart, Andrew. (1991). Understanding the Media. London: Routledge.

Lasker, Albert. (1963). The Lasker Story: As He Told It. Chicago: Advertising Publications.

Leech, Geoffrey. (1966). English in Advertising: A Linguistic Study of Advertising in Great Britain. London: Longman.

Leonard De Vries. (1968). Victorian Advertisements. London: William Clowes and Sons Limited.

Mai Xuan Huy. (2005). Advertising Language. Hanoi: Social Science Publishing House.

Marchand, Roland. (1985). Advertising the American Dream. Berkeley: University of California Press.

Nguyen Duc Ton, Tran Dinh Vinh. (1993). Language in Advertisements. Linguistics, 1, 39-46.

Randazzo, Sal. (1993). Mythmaking on Madison Avenue. Chicago: Probus Publishing.

Scholes, Robert, \& Comely, Nancy. (1989). The Practice of Writing. New York: St. Martin's Press Inc.

Sells, Peter, \& Sierra Gonzalez. The Language of Advertising. Retrieved from http://www.stanford.edu/class/linguist34/index.htm

Vestergaard, T., \& Schroder, K. (1985). The Language of Advertising. Oxford: Basil Blackwell.

Williams, Raymond. (1980). Advertising: The Magic System. Problems in Materialism and Culture. London: Verso. 